\title{
Factors Affecting the Knowledge and Motivation of Health Cadres on Stunting Prevention in Children in Indonesia
}

\author{
Henny Suzana Mediani ${ }^{1^{*}}$, Sri Hendrawati ${ }^{2}$, Tuti Pahria ${ }^{3}$, Ati Surya Mediawati ${ }^{3}$ and Mira \\ Suryani \\ ${ }^{1}$ Department of Pediatric Nursing, Faculty of Nursing, Universitas Padjadjaran Indonesia; \\ henny.mediani@unpad.ac.id \\ 2 Department of Pediatric Nursing, Faculty of Nursing, Universitas Padjadjaran Indonesia; \\ sri.hendrawati@unpad.ac.id \\ ${ }^{3}$ Department of Medical and surgical Nursing, Faculty of Nursing, Universitas Padjadjaran Indonesia; \\ t.pahria@gmail.com \\ ${ }^{4}$ Department Fundamental of Nursing, Faculty of Nursing, Universitas Padjadjaran Indonesia; \\ ati.meidiawati@unpad.ac.id \\ ${ }^{5}$ Department of Computer Science, Math and Science Faculty Universitas Padjadjaran; \\ mira.suryani@unpad.ac.id
}

* Correspondence: henny.mediani@unpad.ac.id ;

\begin{abstract}
Stunting in children is a serious problem of nutritional disorders and is strictly monitored by the Indonesian government, it is not only cause physical but also cognitive abnormalities in the form of less intelligence in children so that when they grow up, their productivity will decrease. The incidence of stunting in 2018 in Indonesia was $30.8 \%$, while in West Java was $29.92 \%$, still at a moderate to high level, consequently, prevention and early detection efforts need to be carried out by various parties, including health professionals and health cadres. Therefore, the aim of this study was to examine the association between the socio demographic characteristics factors as well as the knowledge and motivation of health cadres in the stunting prevention in West Java. A correlational study with a cross-sectional approach was employed with the samples of health cadres from 8 districts/cities in West Java Province: Karawang, Tasikmalaya, Garut, Bandung, Subang, Sukabumi, Cianjur, and West Bandung. A total of 363 health cadres participated and the sampling technique used is the stratified method. The data were collected using a questionnaire developed specifically for this study and were analyzed using a correlation with Chi-Square test and presented in the form of a frequency distribution. The study findings found that majority of the health cadres have good knowledge of $81.27 \%$, which was significantly influenced by education level and marital status with $\mathrm{p}<0.05$. Meanwhile, approximately half of the respondents had moderate motivation with $47.66 \%$, while one-third or $39.12 \%$ had high motivation. This motivation was significantly influenced by education level, marital status, and age with $\mathrm{p}<0.05$. It was concluded that health cadres need to further enhance the roles and functions in the prevention and early detection of stunting in West Java by providing continuous guidance, stunting training prevention and award presentations.
\end{abstract}

Keywords: Health cadres, knowledge, motivation, stunting children, stunting prevention, 


\section{Introduction}

Stunting is one of the nutritional problems experienced by children under five globally with a high prevalence in developing countries including Indonesia, where in 2016 as many as $22.9 \%$ or 154.8 million children under five experience stunting, while in 2017 it became $22.2 \%$ or around 150.8 million children under five in developing countries experience stunting (1). According to the 2014 Global Nutrition Report, Indonesia is one of the top 17 countries out of 117 countries that have three nutritional problems, one of which is stunting. As many as $56 \%$ of short children live in Asia and $36 \%$ in Africa (2). Children with this condition are considered stunted with characterized by a $\mathrm{Z}$ score for body length for age $(\mathrm{PB} / \mathrm{U})$, or height for age $(\mathrm{TB} / \mathrm{U})$, weight for age $(\mathrm{W} / \mathrm{U})$, and weight for height (W/TB) less than -2 SD (3). Approximately $30 \%$ of under five years old children are stunted (4-6).

Stunting is one of the main nutritional problems that are still experienced by Indonesian children under five years. Indonesia is included in the top five countries with the highest prevalence in AsiaAfrica (2) with approximately 9 million affected children out of the 24.5 million population (7). The stunting prevalence in children under five years from 2007 to 2018 is still above the threshold set by WHO, which is 20\%. In 2007 it reached 36.8\%, in 2010 it reached 35.6\%, in 2013 it reached $37.2 \%$ and in 2018 it was 30.8\% (8). Meanwhile, West Java is the second province in Indonesia with the largest population and has a stunting prevalence rate of $29.2 \%$ or 2.7 million under five years old children (9). This figure is in the medium level, while above $30 \%$ indicates a high prevalence. When compared with the non-public health problem limit according to WHO for stunting, West Java is one of the provinces in Indonesia that is still in a problematic condition (10).

Stunting occurs due to lack of adequate nutrition (malnutrition), particularly in the First 1000 Days of Life (11-16). Malnutrition at an early age increases infant and child mortality, and stunting is estimated to cause approximately one million child deaths every year $(15,16)$, leading to frequent illness and bad posture during adulthood in affected persons (17). The adverse impacts of stunting in the short term can cause disturbance of the brain, intelligence, impaired physical growth, and metabolic disorders in the body $(15,16,18)$. In the long term, the bad consequences that can be caused are declined cognitive abilities and learning achievement, decreased immunity so that it is easy to get sick, high risk of diabetes, obesity, heart and blood vessel disease, cancer, stroke and disability in old age, as well as poor quality of work. uncompetitive which results in low economic productivity $(8,11,12,16,19)$.

Several studies reported that various factors contribute to the incidence of stunting in children, such as parenting, exclusive breastfeeding practices, psychosocial stimulation, poor hygiene and environmental sanitation, especially in densely populated areas, as well as remote and demographic factors $(10,17,20,21)$. Other basic factors include economic influence, mother's education, as well as intermediates such as the number of family members, mother's height and age, as well as the number of mother's children $(17,22,23)$. This is followed by proximal factors such as exclusive breastfeeding, age, and infants with low birth weight (LBW) $(10,24)$.

The Indonesian government has made regulations to reduce stunting rates, including by issuing Presidential Regulation Number 42 of 2013 concerning the National Movement for the Acceleration of Nutrition Improvement which focuses on the First 1000 Days of Life (1000 HPK), this movement aims to increase effectiveness and initiatives by increasing coordination and technical support, advocacy Innovative and participatory partnership in improving the nutritional status and health of people in Indonesia, with priority on $1000 \mathrm{HPK}$, but the rate has not decreased. This effort has not been balanced with the knowledge, attitudes and behavior of parents, family supports and health cadres in making efforts to prevent stunting as early as possible or in the first $1000 \mathrm{HPK}$.

Health cadres in integrated healthcare center (Posyandu) play an important role by bridging the gap between healthcare providers and the community in providing information related to health, such as child growth and development (13). Stunting prevention in the community is implemented by involving health cadres in the respective working areas. The involvement of cadres in the implementation of the stunting program in accordance with the pillars of handling stunting in Indonesia at the 3rd point, namely convergence, coordination, and consolidation of national programs, as mentioned in Rural ministry regulations PDTT No. 192017 at the 9th point, namely the 
implementation of community empowerment in the promotion of public health, healthy living in which includes the sub-point of involvement of health cadres by holding a posyandu cadre meeting.

Health cadres need to have the basic requirements, including the knowledge and skills to maximize respective roles. The role of cadres tends to be more optimal with having a high motivation (25). Based on previous studies, majority of the health cadres have fairly good knowledge on the development and early detection of malnutrition in children under five years $(26,27)$. Meanwhile, the active role of the health cadres is based on age, education, occupation, and length of work, therefore, age is an indirect contributing factor that affects the experience of cadres in preventing stunting among children under five years. However, there are still clear gaps on the effect of internal factors, including cadre knowledge and motivation on the efforts to prevent stunting in children. Therefore, this study aims were to identify the associations sociodemographic characteristics with the knowledge and motivation of health cadres in stunting prevention in West Java.

\section{Materials and Methods}

2.1 Research methods. This study was carried out based on a cross-sectional approach with a correlational analytic method to examine the relationship between the characteristics as well as the knowledge and motivation of health cadres in the stunting prevention in West Java. Therefore, it determined the relationship between the independent and the dependent variable by making instantaneous measurements (28).

2.2 Study location. The study was conducted in 8 districts/cities in West Java namely Bandung, West Bandung, Garut, Tasikmalaya, Cianjur, Subang, Sukabumi, and Karawang between August 2020Desember 2020.

2.3 Sampling design. The stratified simple random sampling technique was used by taking groups with simple randomness as respondents (29). A total of 363 health cadres from 8 districts/cities in West Java participated in this study.

2.4. Data collection. The data were collected using a questionnaire consisting of the respondents' demographics as well as the knowledge and motivation of health cadres in stunting prevention. Meanwhile, the questionnaire developed was initially analyzed through content and a constructed test on validity and reliability.

2.5 Stastictical analysis. A descriptive univariate analysis was the first section presenting the percentage of response to each variables. Bivariate analysis comprised a Chi-square score analysis was conducted to assess the relation between health cadres' characteristics (occupation, education, marital status and age), with the knowledge and motivation of stunting prevention in West Java. All statistical analysis was performed using the SPSS Windows Versi 19.0 and statistical significance was set $\alpha=0.05$.

2.6 Ethical consideration. Ethical permission was obtained from Institutional Review Board (IRB) of Universitas Padjadjaran Ethical Committee Bandung, Indonesia number 594/UN6.KEP/EC/2020.

\section{Results}

\subsection{Health cadres' characteristics}

The health cadres' characteristics across the 8 districts/cities are depicted in table 1 . Among the 363 health cadres who participated in the study, a total of 270 or $74.38 \%$ of the respondents have jobs while 93 or $25.62 \%$ are unemployed. In terms of education, there was a great variation of health cadres' education, with 139 or $38.29 \%$ of respondents holding high school, 124 or $34.16 \%$ were diploma/bachelor graduates, 57 or $15.70 \%$ holding junior high school, while 43 or $11,85 \%$ were elementary school graduates. Regarding marital status, majority of the respondent up to 330 or 
$90.91 \%$ are married, 25 or $6.89 \%$ are not married, while 8 or $20.20 \%$ are widowed. In term of age, the mean age health cadres were 39 years.

\subsection{Knowledge and Motivation of Health Cadres in Stunting Prevention}

The health cadres' knowledge and motivation on stunting prevention in children under five years in 8 districts/cities are illustrated in table 2. Based on the results, majority of the respondents already have good knowledge, up to 295 or $81.27 \%$, followed by 36 or $9.92 \%$ with sufficient, and 32 or $8.82 \%$ that lack knowledge.

In term of health cadres' motivation in stunting prevention, results of this study found that the majority of health cadres have moderate motivation related to stunting prevention efforts while 142 or $39.12 \%$ have high motivation. Therefore, it was concluded from Table 2 that most of the health cadres have good knowledge as well as moderate to high motivation about stunting prevention efforts in each district/city.

\subsection{Relationship of Knowledge and Motivation with Occupation of Health Cadres in West Java}

Regarding the association between the knowledge and motivation of health cadres with the occupation in all districts/cities in West Java Province (table 3), it can be seen from result chi-square score analysis that there was no significant relationship between the knowledge and motivation of cadres with the work carried out in all districts/cities in West Java Province (Bandung, West Bandung, Garut, Tasikmalaya, Cianjur, Subang, Sukabumi, and Karawang) as indicated by the probability values generated which were all greater than an error rate of 0.05 or $5 \%$.

\subsection{Relationship of Knowledge and Motivation with Health Cadre Education in West Java}

Results of bivariate analysis regarding the association of Knowledge and Motivation with Health Cadre Education (table 4) shows that there was no significant relationship between knowledge and education as indicated by a probability value greater than an error rate of 0.05 or $5 \%$. However, the value obtained generally in West Java Province was $0.017<0.05$ hence, it was concluded that the overall data has a significant relationship with education which indicates that good knowledge tends to be associated with higher education including Senior High School, Diploma / Bachelor, while sufficient tends to be associated with low education including, Elementary School. Furthermore, table 4 shows that there was no significant relationship between cadre motivation and education as indicated by a probability value greater than an error rate of 0.05 or $5 \%$. A significant relationship was only found in Subang Regency with a p-value of $0.000<0.05$, hence, high motivation tends to be associated with fairly education such as Senior High School and Diploma / Bachelor, while low tends to be associated with relatively low education, i.e, Junior High School.

\subsection{Relationship of Knowledge and Motivation with Marital Status of Health Cadres in West Java}

Result of this study in term of the association of Knowledge and Motivation with Marital Status of Health Cadres in West Java (table 5) found that there was no significant relationship between cadre knowledge and marital status in almost all districts/cities, as indicated by a probability value greater than an error rate of 0.05 or $5 \%$. However, a significant relationship was found in Garut Regency with p-value $0.033<0.05$. As shown in table 5 , there was no significant relationship between motivation and marital status as indicated by a probability value greater than an error rate of 0.05 or $5 \%$. Meanwhile, a significant relationship was found in Tasikmalaya Regency with a p-value of 0.000 $<0.05$, hence, it was concluded that the motivation of health cadres has a significant relationship with marital status, where high motivation tends to be associated with marital status, while low tends to be related to widow/widower status.

3.6 Relationship of Knowledge and Motivation with Age of Health Cadre in West Java 
We analysed relationship of Knowledge and Motivation with Age of Health Cadre in West Java (table 6). It can be seen from the table 6 that there was no significant relationship between knowledge and the age of cadres, both in each district/city and overall in West Java Province. However, there was no significant relationship between motivation and age as indicated by a probability value greater than an error rate of 0.05 or $5 \%$ in all districts/cities studied. In contrast, there was a significant relationship in Subang Regency (p-value $0.013<0.05$ ). It was concluded that cadre motivation has a significant relationship with cadre age, where high motivation tends to be associated with relatively young age ( $<41$ years), while low motivation tends to be associated with old age ( $>50$ years). 
Table 1 Description of the Health Cadre Respondents Characteristics in West Java (n=363)

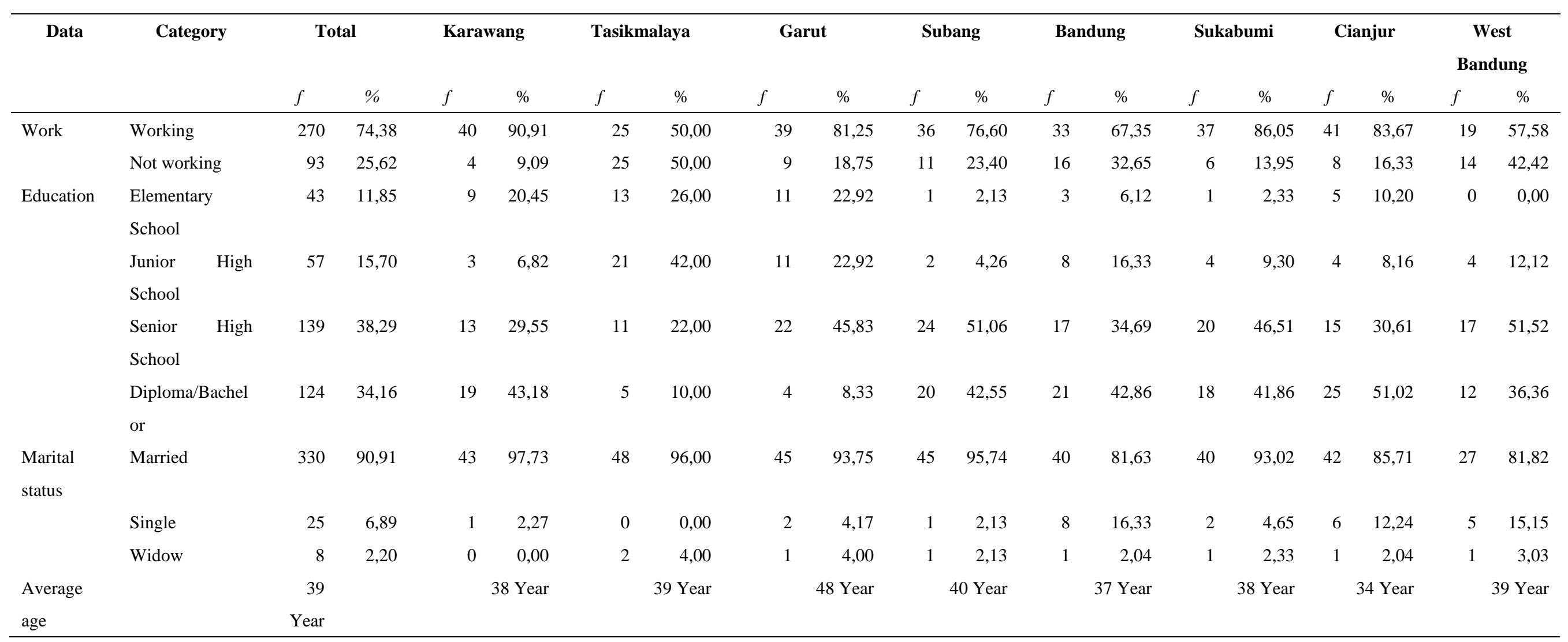




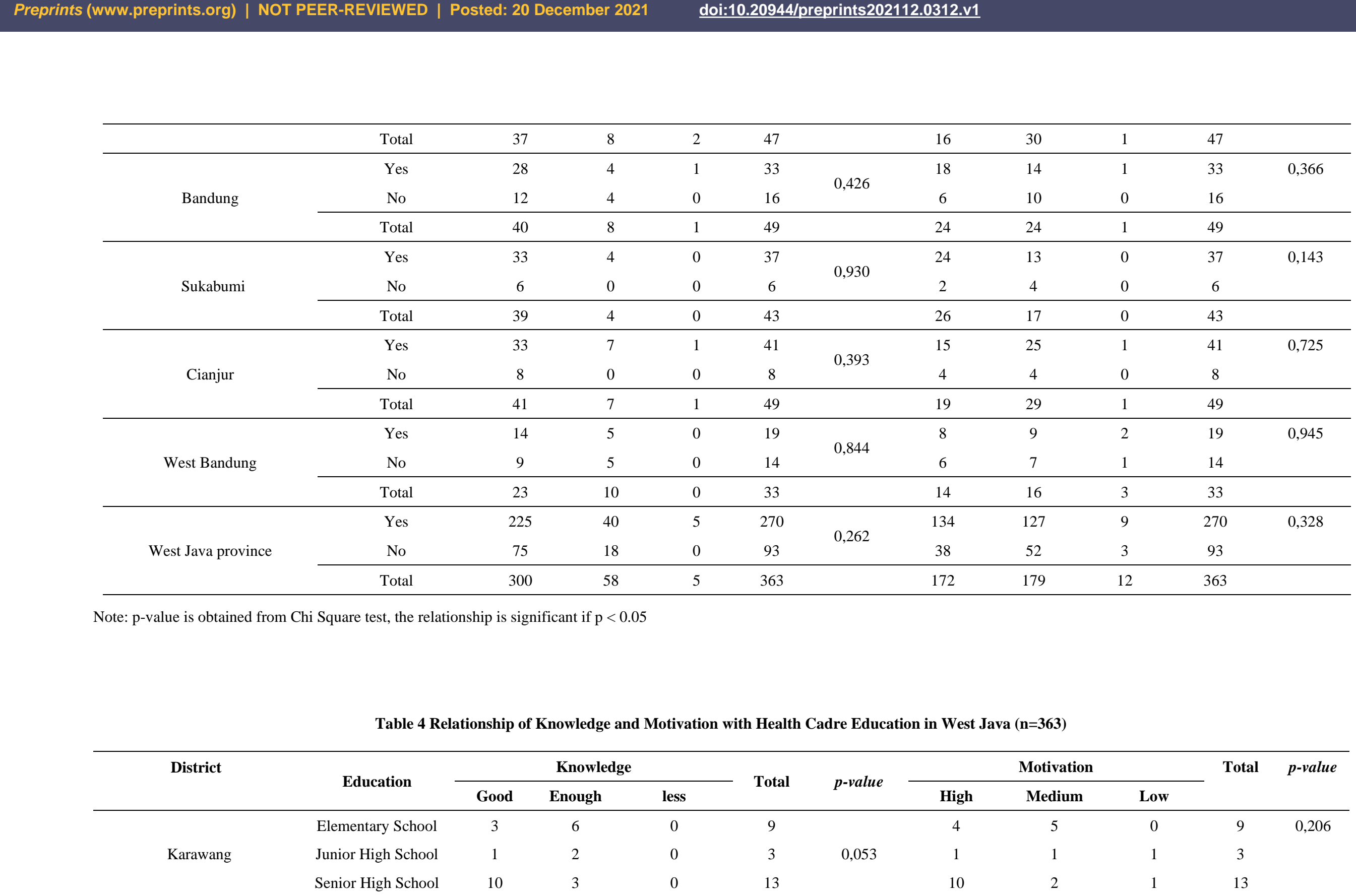

Note: $p$-value is obtained from Chi Square test, the relationship is significant if $p<0.05$

Table 4 Relationship of Knowledge and Motivation with Health Cadre Education in West Java (n=363)

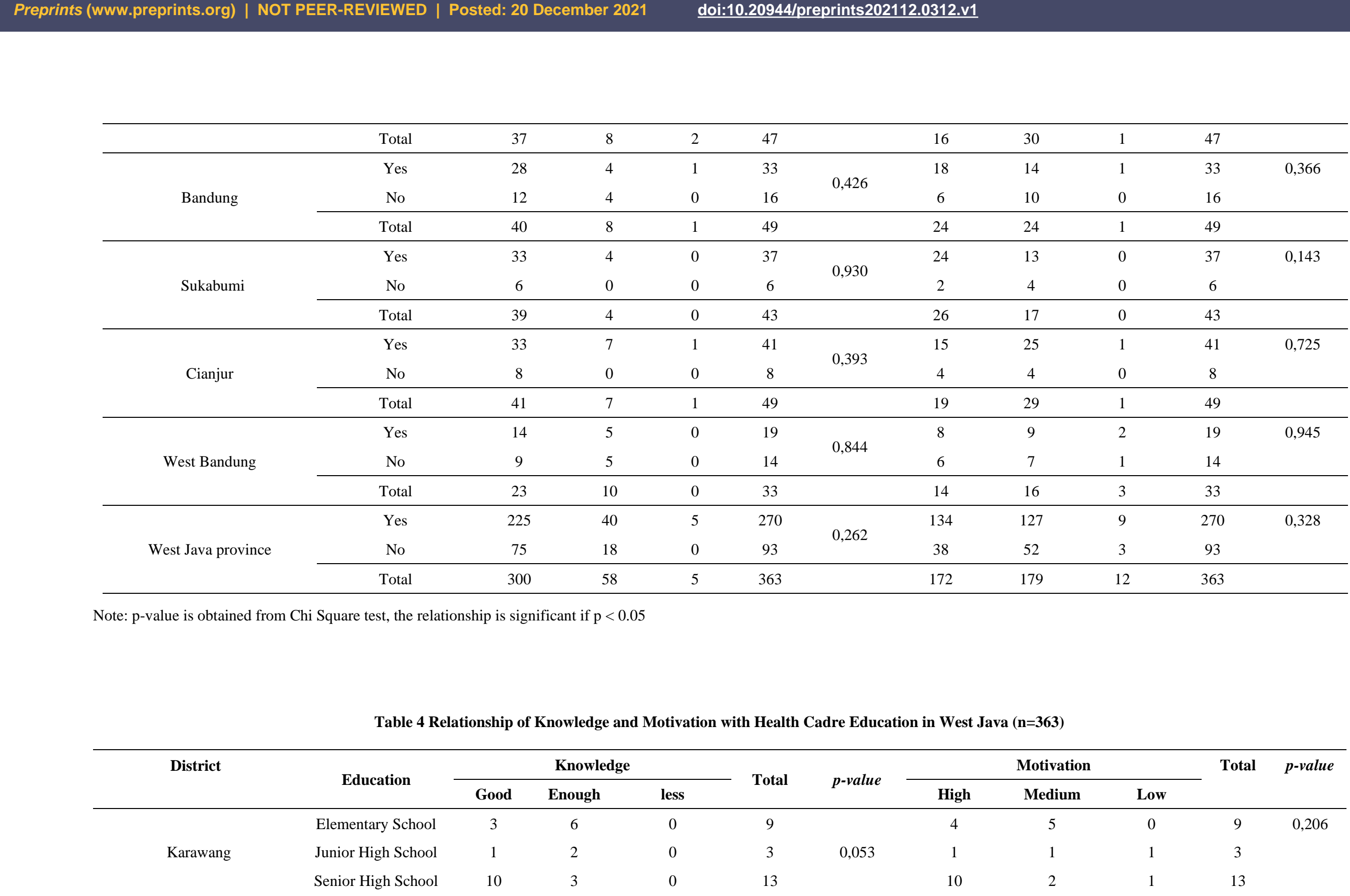




\begin{tabular}{|c|c|c|c|c|c|c|c|c|c|c|c|}
\hline & Diploma/Bachelor & 16 & 2 & 1 & 19 & & 9 & 9 & 1 & 19 & \\
\hline & Total & 30 & 13 & 1 & 44 & & 24 & 17 & 3 & 44 & \\
\hline \multirow{5}{*}{ Tasikmalaya } & Elementary School & 10 & 3 & 0 & 13 & \multirow{4}{*}{0,235} & 5 & 8 & 0 & 13 & \multirow[t]{4}{*}{0,579} \\
\hline & Junior High School & 19 & 2 & 0 & 21 & & 8 & 13 & 0 & 21 & \\
\hline & Senior High School & 11 & 0 & 0 & 11 & & 5 & 5 & 1 & 11 & \\
\hline & Diploma/Bachelor & 5 & 0 & 0 & 5 & & 3 & 2 & 0 & 5 & \\
\hline & Total & 45 & 5 & 0 & 50 & & 21 & 28 & 1 & 50 & \\
\hline \multirow{5}{*}{ Garut } & Elementary School & 9 & 2 & 0 & 11 & \multirow{4}{*}{0,286} & 6 & 3 & 2 & 11 & \multirow[t]{4}{*}{0,261} \\
\hline & Junior High School & 11 & 0 & 0 & 11 & & 6 & 5 & 0 & 11 & \\
\hline & Senior High School & 21 & 1 & 0 & 22 & & 13 & 9 & 0 & 22 & \\
\hline & Diploma/Bachelor & 4 & 0 & 0 & 4 & & 3 & 1 & 0 & 4 & \\
\hline & Total & 45 & 3 & 0 & 48 & & 28 & 18 & 2 & 48 & \\
\hline \multirow{5}{*}{ Subang } & Elementary School & 1 & 0 & 0 & 1 & \multirow{4}{*}{0,857} & 0 & 1 & 0 & 1 & \multirow[t]{4}{*}{$0,000 *$} \\
\hline & Junior High School & 2 & 0 & 0 & 2 & & 1 & 0 & 1 & 2 & \\
\hline & Senior High School & 17 & 6 & 1 & 24 & & 7 & 17 & 0 & 24 & \\
\hline & Diploma/Bachelor & 17 & 2 & 1 & 20 & & 8 & 12 & 0 & 20 & \\
\hline & Total & 37 & 8 & 2 & 47 & & 16 & 30 & 1 & 47 & \\
\hline \multirow{5}{*}{ Bandung } & Elementary School & 2 & 1 & 0 & 3 & \multirow{4}{*}{0,781} & 1 & 2 & 0 & 3 & \multirow[t]{4}{*}{0,149} \\
\hline & Junior High School & 6 & 2 & 0 & 8 & & 1 & 7 & 0 & 8 & \\
\hline & Senior High School & 14 & 2 & 1 & 17 & & 8 & 9 & 0 & 17 & \\
\hline & Diploma/Bachelor & 18 & 3 & 0 & 21 & & 14 & 6 & 1 & 21 & \\
\hline & Total & 40 & 8 & 1 & 49 & & 24 & 24 & 1 & 49 & \\
\hline \multirow{4}{*}{ Sukabumi } & Elementary School & 1 & 0 & 0 & 1 & \multirow{4}{*}{0,664} & 1 & 0 & 0 & 1 & \multirow[t]{4}{*}{0,839} \\
\hline & Junior High School & 4 & 0 & 0 & 4 & & 2 & 2 & 0 & 4 & \\
\hline & Senior High School & 17 & 3 & 0 & 20 & & 12 & 8 & 0 & 20 & \\
\hline & Diploma/Bachelor & 17 & 1 & 0 & 18 & & 11 & 7 & 0 & 18 & \\
\hline
\end{tabular} \\ .0312.v1}




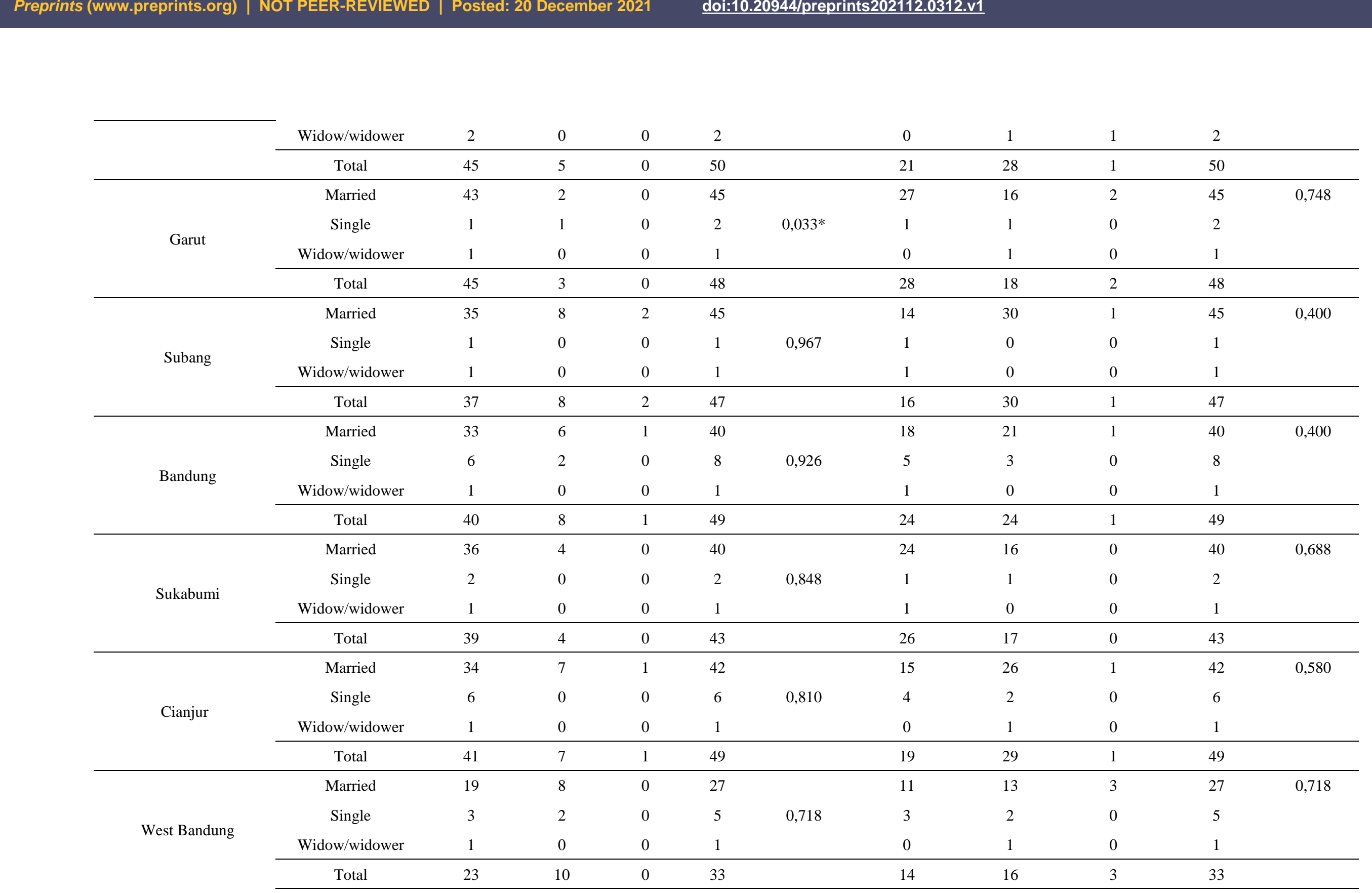




\begin{tabular}{|c|c|c|c|c|c|c|c|c|c|c|c|}
\hline \multirow{4}{*}{ West Java province } & Married & 272 & 53 & 5 & 330 & \multirow{3}{*}{0,672} & 153 & 166 & 11 & 330 & \multirow[t]{3}{*}{0,237} \\
\hline & Single & 20 & 5 & 0 & 25 & & 16 & 9 & 0 & 25 & \\
\hline & Widow/widower & 8 & 0 & 0 & 8 & & 3 & 4 & 1 & 8 & \\
\hline & Total & 300 & 58 & 5 & 363 & & 172 & 179 & 12 & 363 & \\
\hline
\end{tabular}

Note: $\mathrm{p}$-value is obtained from Chi Square test, the relationship is significant if $\mathrm{p}<0.05$

Table 6 Relationship of Knowledge and Motivation with Age of Health Cadre in West Java (n=363)

\begin{tabular}{|c|c|c|c|c|c|c|c|c|c|c|c|}
\hline \multirow[b]{2}{*}{ District } & \multirow[b]{2}{*}{ Age } & \multicolumn{3}{|c|}{ Knowledge } & \multirow[b]{2}{*}{ Total } & \multirow[b]{2}{*}{ p-value } & \multicolumn{3}{|c|}{ Motivation } & \multirow[t]{2}{*}{ Total } & \multirow[t]{2}{*}{$p$-value } \\
\hline & & Good & $\begin{array}{c}\text { Enoug } \\
\mathbf{h}\end{array}$ & less & & & High & Medium & Low & & \\
\hline \multirow{5}{*}{ Karawang } & 20-30 year & 1 & 0 & 0 & 1 & \multirow{4}{*}{0,267} & 1 & 0 & 0 & 1 & 0,370 \\
\hline & $31-40$ year & 4 & 1 & 1 & 6 & & 4 & 2 & 0 & 6 & \\
\hline & 41-50 year & 14 & 8 & 0 & 22 & & 9 & 12 & 1 & 22 & \\
\hline & $>50$ year & 11 & 4 & 0 & 15 & & 10 & 3 & 2 & 15 & \\
\hline & Total & 30 & 13 & 1 & 44 & & 24 & 17 & 3 & 44 & \\
\hline \multirow{4}{*}{ Tasikmalaya } & $31-40$ year & 6 & 1 & 0 & 7 & \multirow{3}{*}{0,106} & 2 & 5 & 0 & 7 & 0,720 \\
\hline & $41-50$ year & 17 & 4 & 0 & 21 & & 9 & 12 & 0 & 21 & \\
\hline & $>50$ year & 22 & 0 & 0 & 22 & & 10 & 11 & 1 & 22 & \\
\hline & Total & 45 & 5 & 0 & 50 & & 21 & 28 & 1 & 50 & \\
\hline \multirow{4}{*}{ Garut } & $31-40$ year & 8 & 2 & 0 & 10 & \multirow{3}{*}{0,109} & 6 & 3 & 1 & 10 & 0,713 \\
\hline & $41-50$ year & 17 & 0 & 0 & 17 & & 11 & 6 & 0 & 17 & \\
\hline & $>50$ year & 20 & 1 & 0 & 21 & & 11 & 9 & 1 & 21 & \\
\hline & Total & 45 & 3 & 0 & 48 & & 28 & 18 & 2 & 48 & \\
\hline \multirow{3}{*}{ Subang } & $31-40$ year & 3 & 1 & 1 & 5 & \multirow{3}{*}{0,375} & 5 & 0 & 0 & 5 & $0,013^{*}$ \\
\hline & $41-50$ year & 17 & 4 & 0 & 21 & & 7 & 14 & 0 & 21 & \\
\hline & $>50$ year & 17 & 3 & 1 & 21 & & 4 & 16 & 1 & 21 & \\
\hline
\end{tabular}

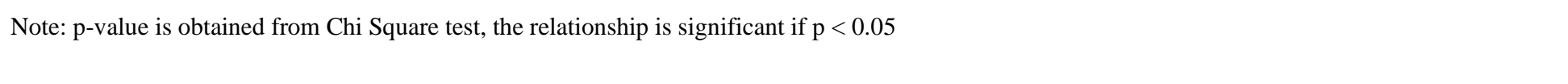




\begin{tabular}{|c|c|c|c|c|c|c|c|c|c|c|c|}
\hline & Total & 37 & 8 & 2 & 47 & & 16 & 30 & 1 & 47 & \\
\hline \multirow{4}{*}{ Bandung } & $31-40$ year & 12 & 2 & 0 & 14 & \multirow{3}{*}{0,842} & 10 & 4 & 0 & 14 & 0,130 \\
\hline & $41-50$ year & 11 & 2 & 0 & 13 & & 6 & 6 & 1 & 13 & \\
\hline & $>50$ year & 17 & 4 & 1 & 22 & & 8 & 14 & 0 & 22 & \\
\hline & Total & 40 & 8 & 1 & 49 & & 24 & 24 & 1 & 49 & \\
\hline \multirow{4}{*}{ Sukabumi } & $31-40$ year & 8 & 0 & 0 & 8 & \multirow{3}{*}{0,237} & 3 & 5 & 0 & 8 & 0,317 \\
\hline & $41-50$ year & 13 & 3 & 0 & 16 & & 10 & 6 & 0 & 16 & \\
\hline & $>50$ year & 18 & 1 & 0 & 19 & & 13 & 6 & 0 & 19 & \\
\hline & Total & 39 & 4 & 0 & 43 & & 26 & 17 & 0 & 43 & \\
\hline \multirow{4}{*}{ Cianjur } & $31-40$ year & 20 & 3 & 0 & 23 & \multirow{3}{*}{0,619} & 8 & 15 & 0 & 23 & 0,289 \\
\hline & 41-50 year & 10 & 2 & 0 & 12 & & 7 & 5 & 0 & 12 & \\
\hline & $>50$ year & 11 & 2 & 1 & 14 & & 4 & 9 & 1 & 14 & \\
\hline & Total & 41 & 7 & 1 & 49 & & 19 & 29 & 1 & 49 & \\
\hline \multirow{4}{*}{ West Bandung } & $31-40$ year & 3 & 4 & 0 & 7 & \multirow{3}{*}{0,138} & 4 & 2 & 1 & 7 & 0,788 \\
\hline & 41-50 year & 8 & 1 & 0 & 9 & & 3 & 5 & 1 & 9 & \\
\hline & $>50$ year & 12 & 5 & 0 & 17 & & 7 & 9 & 1 & 17 & \\
\hline & Total & 23 & 10 & 0 & 33 & & 14 & 16 & 3 & 33 & \\
\hline \multirow{5}{*}{ West Java province } & 20-30 year & 1 & 0 & 0 & 1 & \multirow{4}{*}{0,597} & 1 & 0 & 0 & 1 & 0,726 \\
\hline & $31-40$ year & 64 & 14 & 2 & 80 & & 42 & 36 & 2 & 80 & \\
\hline & $41-50$ year & 107 & 24 & 0 & 131 & & 62 & 66 & 3 & 131 & \\
\hline & $>50$ year & 128 & 20 & 3 & 151 & & 67 & 77 & 7 & 151 & \\
\hline & Total & 300 & 58 & 5 & 363 & & 172 & 179 & 12 & 363 & \\
\hline
\end{tabular}

Note: $p$-value is obtained from Chi Square test, the relationship is significant if $p<0.05$ \\ Preprints (uvw preprints.org) | NOT PEER-REVIEWED | Posted: 20 December 2021 doi:10.20944/preprints202112.0312.v1 \\ doi:10.20944/preprints202112.0312.v1}




\section{Discussion}

This study aim was to identify the associations of socio-demographic characteristics with the knowledge and motivation of health cadres in stunting prevention in West Java. There were no significance associations between socio-demographic characteristic (occupation, education, marital status and age) with health cadre's knowledge and motivation of stunting prevention in West Java.

Health cadres are community members involved by the public healthcare center to manage the integrated healthcare center voluntarily. Furthermore, cadres are also the main pillar for improving the public health status, especially in the prevention of stunting. The results showed that the majority of health cadres have good knowledge as well as moderate to high motivation regarding stunting prevention efforts. This finding is applicable as initial capital for the provision of health cadres to the community as part of the stunting prevention efforts. Furthermore, the data from the 8 districts/cities namely Karawang, Tasikmalaya, Garut, Bandung, Subang, Sukabumi, Cianjur, and West Bandung show that the average age was 39 years and the majority have senior high school education/diplomas/graduates which tend to strengthen the role of health cadres. Based on the results, at a productive age supported by fairly high education, good knowledge, and high motivation, health cadres tend to carry out respective functions appropriately in collaboration with professional health workers in the work areas.

The knowledge on stunting and preventive measures is good, possibly because the cadres have attended the training held in the district/city and are supported by health professionals such as midwives and public health center nurses. A study conducted in the public health center area of Bandung City found that health cadres attended stunting prevention training several times during the implementation of integrated healthcare center and were always evaluated by the midwives and nurses. Cadres are also guided on how to find stunting cases in the community. Singh et al. found that a conducive support system with assistance from health workers tends to increase the knowledge of health cadres (30), while Permatasari, Nurika, and Damayanti reported that training is an activity carried out to improve skills, knowledge, and attitudes to improve performance (31)

Notoatmodjo showed that a person's knowledge is influenced by age, education, occupation, sources of information, experience, social status, economy, culture, and the environment (32). Based on the results, there is a significant relationship between knowledge and education which indicates that good knowledge tends to be associated with fairly high/high education including Senior high school, Diploma/Bachelor, while sufficient tends to be associated with low education such as Elementary School. There is also a significant relationship between knowledge and marital status in Garut Regency with a p-value of $0.033<0.05$. The knowledge level is one of the factors that affect the performance of integrated healthcare center, while notion is the first part of this level. Meanwhile, understanding generates knowledge, therefore, it constitutes a major part of the level (32).

The results indicate that occupation and age have no significant effect on knowledge. This is not consistent with Muthmainna which stated that there is a significant relationship between work and knowledge (33). Furthermore, there is no relationship between the occupation and knowledge in relation to stunting prevention because the majority of health cadres do not work with sufficient knowledge. This is also possible because both health cadres with or without jobs have a similar experience and opportunity to obtain information and participate in various training held by agencies or government for stunting prevention and control. This is in line with Wardani et al. which stated that there is no significant relationship between work and knowledge of health cadres (34).

Furthermore, the results of this current study are not consistent with Astuti which reported that there is a relationship between age and knowledge level, as the respondents' age ranged from 20-35 years (35). Meanwhile, the majority of respondents in this study were in the age group of $>35$ years - 50 years. This age range is associated with a good pattern of comprehension and thinking power, hence, the knowledge also better (32) as also stated by (34).

The role of health cadres related to child nutrition problems, especially stunting, is to carry out early detection by weighing and measuring the length or height of children properly as well as regularly every month and record in the Health Monitoring Card (KMS). Cadres also provide counseling to parents on the characteristics of stunting children as well as the preventive measures 
(36) and play an important role in conveying health information related to the dangers and impacts to reduce the risk in children under five years old in the community.

Improving the cognitive aspects of health cadres is very important, while several studies reported that knowledge influences a person's behavior $(33,35)$. Knowledge is the outcome of understanding, and this occurs after people have sensed a certain object through the human senses, namely sight, hearing, smell, taste, and touch. The majority of human knowledge is obtained through the eyes and ears, while cognitive knowledge plays an important role in shaping overt behavior (32).

Notoatmodjo stated that an increase in knowledge leads to changes in one's perceptions, habits, and beliefs (32). Based on experience and several studies research, a long-lasting behavior depends on knowledge, awareness, and a positive attitude and vice versa (32). Therefore, increasing the cognitive aspect, in this case, the knowledge of health cadres is important to prevent stunting problems in the community.

External motivation is triggered from the outside, while the internal comes from an individual's initiative. Samsudin stated that motivation is a process of influencing or encouraging a person or group to carry out a particular task. It is also a driving force or a natural urge to satisfy and sustain life (37).

A person's motivation is influenced by internal and external factors (38). The internal consists of inner desire, knowledge level, education, self-management, and age, while external factors consist of family support, religion, and reinforcement/strength. Purwanto stated that motivation is influenced by needs, attitudes, and interests (39). Based on the results, there is a significant relationship with education, where high motivation tends to be associated with moderate to high education including Senior High School and Diploma/Bachelor, while low tends to be associated with relatively low education such as Junior High School. In addition, there was significant relationship with marital status, where high motivation tends to be associated with marital status, while low tends to be associated with widow/widower status. This study also found a significant relationship with age, where high motivation tends to be associated with relatively young age $(<41$ years), while low tends to be associated with old age ( $>50$ years). However, there is no significant relationship with work.

Motivation has a significant relationship with education related to knowledge. The higher the knowledge, the higher the motivation of health cadres in carrying out respective roles. Meanwhile, marital status in the form of husband/family support also increases motivation. Moreover, the majority of health cadres are in the age range of 36-50 years, hence, it was concluded that high motivation is associated with a relatively young age. This is supported by Haryani which stated that awards, family support, environment, and knowledge influence the motivation of cadres in carrying out activities at Integrated Health Post (25).

Susanto et al. stated that the roles of health cadres in community empowerment include health motivator, educator, and service provider (40). Meanwhile, community empowerment is formed from motivational factors to improve family and community health, the ability to identify needs and barriers to health services as well as understand the available resources. Therefore, it was concluded that health cadres have an important role in improving health status, especially stunting prevention in the community. However, there are certain limitations in providing health services given that cadres are not health workers.

Health cadres' efforts in preventing stunting among children include activities at the integrated health center or home visits. Meanwhile, age, attitude, motivation, knowledge, years of service, incentives, and training are factors that affect the performance of health cadres (41). Profita stated that knowledge, motivation, and support from various parties are needed to encourage activeness in health cadres in the Integrated Health Post (42). In addition, continuous coaching and reward increase the active participation of health cadres.

This study did not explore how various factors including demographics, self-efficacy, and length of time influence the actual performance of health cadres in stunting prevention efforts. Another aspect that needs to be studied is the experience of cadres in stunting prevention efforts as well as the inhibiting and supporting factors in the community. The results obtained provide a basis for further studies to develop an integrated model of prevention and treatment of stunting in children based on community empowerment in West Java Province. 


\section{Conclusions}

Health cadres play an important role in stunting prevention efforts. The results showed that the majority of health cadres respondents have good knowledge of stunting prevention efforts in each district/city of West Java Province. This is influenced by the education level and marital status, while occupation and age had no significant effect. Furthermore, the majority of the health cadres had high and moderate motivation which is influenced by education level, marital status, and age, while occupation had no significant effect.

These results are applicable as initial capital for the provision of health cadres for the community in preventing stunting. Furthermore, the average age was 39 years and the majority have a fairly high level of education which strengthens the role of health cadres. At a productive age supported by higher education, good knowledge, and high motivation, health cadres effectively carry out respective functions in improving health status of children through collaboration with healthcare professionals at integrated healthcare center.

To achieve the optimal stunting reduction target, healthcare providers such as nurses, midwifes need to review and design appropriate intervention strategies, particularly in children under five. This is expected to enhance the Healthy Indonesia program at the sub-district and district levels. Meanwhile, parents and families need to provide adequate nutrition for the children and maintain good environmental sanitation to empower family functions in preventing stunting and improving the life quality. Furthermore, health cadres need to improve respective roles and functions to empower families and communities as well as to prevent and detect stunting in West Java.

Author Contributions: Conceptualization, H.S.M. and S.H.; methodology, H.S.M.; formal analysis, H.S.M, and, T.P; investigation, S.H., A.S.M, T.P, M.S.; writing - original draft preparation, H.S.M and S.H.; writing - review and editing, H.S.M. All authors have read and agreed to the published version of the manuscript

Funding: This research was funded by the Ministry of Education, Culture, Research and Technology Republic of Indonesia under PTUPT Research Grant.

Acknowledgments: We would like to thank the participants of this study who had spent their time to voluntarily.

Conflicts of Interest: The authors declare no conflict of interest.

\section{References}

1. WHO. Reducing stunting in children: Equity considerations for achieving the Global Nutrition Targets 2025. 2018;

2. Ministry of Health Republic of Indonesia. Pusat data dan informasi Kementerian Kesehatan RI. Jakarta: Ministry of Health Republic of Indonesia; 2017.

3. World Health Organization (WHO). Prevalence of stunting. Geneva; 2019

4. UNICEF/WHO/World Bank Group. Levels and trensds in child malnutrition 2018. In: Joint Child Malnutrition Estimates 2018 edition. 2018. p. 1-15.

5. Kementerian Kesehatan RI. Keputusan Menteri Kesehatan Republik Indonesia Nomor 1995/Menkes/SK/XII/2010 tentang Standar Antopometri Penilaian Status Gizi Anak. Jakarta: WHO; 2011.

6. Okoh M. Socio-demographic correlates of overweight and obesity among women of reproductive age in Nigeria. Afr J Reprod Heal. 2013;17(4):66-76.

7. Rachmi CN, Agho KE, Li M, Baur LA. Stunting, underweight and overweight in children aged 2.0-4.9 years in Indonesia: Prevalence trends and associated risk factors. PLoS One. 2016;11(5):1-17.

8. Ministry of Health Republic of Indonesia. Basic health research [Riskesdas] [Internet]. Jakarta; 2018. Available from: http://www.depkes.go.id/resources/download/info- terkini/materi_rakorpop_2018/ Hasil20Riskesdas 202018.pdf

9. Badan Perencanaan Pembangunan Daerah Jawa Barat. Cegah stunting, Jabar akan gelar kampanye zero 
stunting 2023 [Internet]. 2018. Available from: http://bappeda.jabarprov.go.id/cegah-stunting-jabarakan-gelar-kampanye-zero-stunting-2023/

10. Mediani HS. Predictors of Stunting Among Children Under Five Year of Age in Indonesia: A Scoping Review. Glob J Health Sci. 2020;12(8):83.

11. Bloem MW, de Pee S, Hop LT, Khan NC, Laillou A, Minarto, et al. Key strategies to further reduce stunting in Southeast Asia: lessons from the ASEAN countries workshop. Food Nutr Bull. 2013;34(2 Suppl):8-16.

12. Anugraheni HS, Kartasurya MI. Faktor Risiko Kejadian Stunting Pada Anak Usia 12-36 Bulan Di Kecamatan Pati, Kabupaten Pati. J Nutr Coll [Internet]. 2012;1(1):30-7. Available from: http://ejournals1.undip.ac.id/index.php/jnc

13. Ministry of Health of the Republic of Indonesia. Prevent Stunting, that's Important. Jakarta; 2019.

14. Purwandini K, Kartasurya MI. Pengaruh pemberian micronutrient sprinkle terhadap perkembangan motorik anak stunting usia 12-36 bulan. J Nutr Coll [Internet]. 2013;2(1):50-9. Available from: http://ejournal-s1.undip.ac.id/index.php/jnc

15. Crookston BT, Penny ME, Alder SC, Dickerson TT, Merrill RM, Stanford JB, et al. Children who recover from early stunting and children who are not stunted demonstrate similar levels of cognition. J Nutr. 2010;140(11):1996-2001.

16. Aguayo, Menon. Introduction stop stunting: Improving child feeding, women's nutrition and household sanitation in South Asia. Matern Child Nutr. 2016;12(1):3-11.

17. Sutarto, Mayasari D, Indriyani R. Stunting, Risk Factors and Prevention. J Agromedicine I. 2018;5(1):540-5.

18. Dewey KG, Begum K. Long-term consequences of stunting in early life. Matern Child Nutr. 2011;7(SUPPL. 3):5-18.

19. Hossain M, Choudhury N, Abdullah KAB, Mondal P, Jackson AA, Walson J, et al. Evidence-based approaches to childhood stunting in low and middle income countries: A systematic review. Arch Dis Child. 2017;102(10):903-9.

20. Maywita E. Risk Factors Cause the Stunting of Age 12-59 Months in Kampung Baru Kec. Lubuk Begalung in 2015. J Ris Hesti Medan Akper Kesdam I/BB Medan. 2018;3(1):56.

21. Umeta M, West CE, Verhoef H, Haidar J, Hautvast JGAJ. Factors associated with stunting in infants aged 5-11 months in the Dodota-Sire District, Rural Ethiopia. J Nutr. 2003;133(4):1064-9.

22. Victora CG, Adair L, Fall C, Hallal PC, Martorell R, Richter L, et al. Maternal and child undernutrition: consequences for adult health and human capital. Lancet. 2008;371(9609):340-57.

23. Black RE, Victora CG, Walker SP, Bhutta ZA, Christian P, De Onis M. Maternal and child undernutrition and overweight in low-income and middle-income countries. Matern Child Nutr. 2013;382(9890):42751.

24. Darteh EK, Acquah E, Kyereme AK. Correlates of stunting among children in Ghana. J BMC Public Heal. 2014;14(504).

25. Haryani D. Analisis faktor yang mempengaruhi motivasi kader dalam melaksan akan posyandu lansia di Desa Ledug Kabupaten Banyumas Tahun 2014. Universitas Muhammadiyah Purwokerto; 2014.

26. Agustin A, Rakhmawati W, Nurlita L. Gambaran Pengetahuan Kader di Posyandu Desa Cipacing tentang Perkembangan Balita. Student e-Journal. 2012;1(1):169-72.

27. Adistie F, Maryam NNA, Lumbantobing VBM. Pengetahuan Kader Kesehatan Tentang Deteksi Dini Gizi Buruk pada Balita. J Apl Ipteks untuk Masy [Internet]. 2017;6(3):173-7. Available from: http://jurnal.unpad.ac.id/dharmakarya/article/view/10319/7705 
28. Sastroasmoro S, Ismael S. Dasar-Dasar Metodologi Penelitian Klinis. 5th ed. Jakarta: Sagung Seto; 2014.

29. Creswell JW. Qualitative inquiry \& research design: Choosing among five approaches. 3rd ed. Los Angeles: Sage; 2013.

30. Singh A, Upadhyay AK, Kumar K. Birth size, stunting and recovery from stunting in Andhra Pradesh, India: Evidence from the young lives study. Matern Child Health J. 2016;21.

31. Permatasari ED, Nurika G, Damayanti NA. Capacity Building in Health Worker as an Alternative Solution to Solve Stunting Problem. Indian J Public Heal Res Dev. 2019;10(8):1409-14.

32. Notoatmodjo. Ilmu Perilaku Kesehatan. Jakarta: Rineka Cita; 2014.

33. Muthmainnah F. Faktor-faktor yang berhubungan dengan pengetahuan ibu dalam memberikan makanan pendamping air susu ibu di Puskesmas Pamulang Tahun 2010. UIN Syarif Hidayatullah; 2010.

34. Wardani NI, SR DS, Masfiah S. Factors related with level of health volunteers knowledge about thalassaemia in sumbang district banyumas regency. J Kesmasindo. 2014;6(3):194-206.

35. Astuti HP. Hubungan karakteristik ibu hamil dengan tingkat pengetahuan tentang tanda bahaya pada kehamilan di Puskesmas Sidoharjo Kabupaten Sragen. JurnalStikes Kusuma Husada. 2011;

36. Astuti S. Gerakan Pencegahan Stunting Melalui Pemberdayaan Masyarakat Di Kecamatan Jatinangor Kabupaten Sumedang. Dharmakarya. 2018;7(3):185-8.

37. Samsudin S. Manajemen sumber daya manusia. Bandung: Pustaka Setia; 2005.

38. Handoko TH. Manajemen personalia dan sumber daya manusia. Yogyakarta: BPFE; 2012.

39. Purwanto N. Psikologi pendidikan. Bandung: Remaja Rosdakarya; 2010.

40. Susanto F, Claramita M, Handayani S. Role of posyandu cadres in empowering the community of Bintan. Ber Kedokt Masy. 2017;33(1):13.

41. Andira RA, Abdullah AZ, Sidik D. Factors associated with cadres performance in the posyandu activities in district bontobahari bulukumba in 2012. Hasanuddin Univ Repos. 2012;1-13.

42. Profita AC. Factors Associated with the Activeness of Cadres in Maternal and Baby Clinic of Pengadegan Village Banyumas District. J Adm Kesehat Indones. 2018;6(2):68. 